\title{
UJI EFEK ANTIPIRETIK EKSTRAK DAUN SIRSAK (Annona muricata L.) SECARA ORAL TERHADAP MENCIT (Mus musculus).
}

\author{
Viani*, Hijratul \\ Laboratorium Fitokimia- Farmakognosi Penelitian dan Pengembangan \\ Akademi Farmasi Medika Nusantara yayasan Pelita Mas Palu \\ *Email: viani.anggi@gmail.com
}

\begin{abstract}
ABSTRAK
Telah dilakukan penelitian uji efek antipiretik ekstrak daun sirsak (Annona muricata L.) secara oral terhadap mencit (Mus musculus). Penelitian ini bertujuan untuk mengetahui efek antipiretik ekstrak daun sirsak (Annona muricata L.) secara oral pada mencit (Mus musculus). Pengumpulan data dilakukan dengan mengukur suhu rektal pada mencit (Mus musculus). Hewan percobaan yang digunakan adalah mencit jantan yang berjumlah 10 ekor yang dibagi menjadi 5 kelompok dimana kelompok 1 sebagai kontrol negatif diberikan aquadest, kelompok 2, 3, dan 4 sebagai kelompok uji masing-masing diberikan ekstrak daun sirsak dengan konsentrasi 20\%, 40\%, 60\%, dan untuk kelompok 5 sebagai kontrol positif yang diberikan suspensi parasetamol.. Sebelum diberi perlakuan mencit terlebih dahulu diinduksi dengan larutan pepton yang merupakan faktor penyebab demam. Dimana dari hasil penelitian yang dilakukan menunjukan bahwa ekstrak daun sirsak (Annona muricata L.) memiliki efek Antipiretik terhadap mencit dan efek antipiretik dari ekstrak daun sirsak mempunyai perbedaan efektifitas terlihat pada konsentrasi $60 \%$ dibandingkan dari konsentrasi $20 \%$ dan $40 \%$.
\end{abstract}

Kata Kunci : Efek antipiretik, ekstrak, daun sirsak, mencit.

\begin{abstract}
Has conducted research antipyretic effect of soursop leaf extract (Annona muricata L.) orally to mice (Mus musculus). This study aims to determine the antipyretic effect of leaf extract of soursop (Annona muricata L.) orally in mice (Mus musculus). The collection is done by measuring the rectal temperature in mice (Mus musculus). Experimental animals used were male mice were 10 tails were divided into 5 groups where group 1 as negative controls given distilled water, group 2, 3, and 4 as the test groups were each given extracts of soursop leaves with a concentration of 20\%,40\%,60\%, and for groups of 5 as a positive control given paracetamol suspension, Before the treated mice were first induced by peptone solution which is a causative factor of fever. Where the results of research carried out showed that the extract of leaves of the soursop (Annona muricata L.) has Antipyretic effect on mice and antipyretic effect of soursop leaf extract has a visible difference in effectiveness at a concentration of $60 \%$ compared to a concentration of $20 \%$ and $40 \%$.
\end{abstract}

Keywords: antipyretic Effects, extracts, soursop leaves, mice. 


\section{PENDAHULUAN}

Obat tradisional sudah lama digunakan secara luas di Indonesia. Dalam perkembangan kedokteran modern sekarang ini, masih sangat terasa modern apalagi dizaman krisis seperti ini, harga obat semakin mahal. Pemerintah semakin berusaha untuk menggalakan pemanfaatan obat tradisional sebagai obat alternatif. Obat tradisional merupakan bahan atau ramuan bahan yang berupa bahan tumbuhan, hewan, bahan mineral dan sediaan atau campuran dari bahan tersebut yang secara turun temurun telah digunakan untuk pengobatan berdasarkan pengalamannya. ${ }^{(1,2,3)}$

Bahan-bahan yang bersifat antipiretik memungkinkan merubah suhu normal. Demikian pula bahan-bahan yang mempengaruhi susunan syaraf pusat atau metabolisme hewan mempengaruhi suhu. Sehingga tanaman yang dikenal mungkin menurunkan suhu normal. Daun sirsak banyak mengandung flavonoid yang bermanfaat sebagai antipiretik. (3). Salah satu tumbuhan berkhasiat obat di antaranya adalah sirsak (Annona muricata L.) merupakan tanaman tropis yang buahnya memiliki aroma dan rasa khas. Namun, seiring dengan penelitian terhadap tanaman tersebut, kini populer sebagai tanaman obat. Bagian tanaman sirsak, mulai dari daun, bunga, buah, biji,akar, sampai kulit batang dan akarnya dapat dimanfaatkan sebagai obat. ${ }^{(3)}$

Untuk itu berdasarkan latar belakang tersebut dilakukan penelitian ini dengan tujuan Untuk mengetahui ada tidaknya efek antipiretik ekstrak Daun Sirsak (Annona muricata L.) pada mencit (Mus musculus) dan Untuk mengetahui perbedaan signifikan efektifitas Daun Sirsak (Annona muricata L.) sebagai antipiretik pada mencit (Mus musculus). Adapun manfaat dari penelitian ini yaitu untuk memberikan informasi ilmiah kepada masyarakat tentang efek antipiretik ekstrak Daun Sirsak (Annonamuricata L.) pada mencit (Mus musculus).

\section{METODE PENELITIAN}

\section{Pengambilan sampel}

Pengambilan sampel dilakukan dengan menggunakan tangan secara langsung (pemetikkan). Waktu pengambilan sampel dilakukan pada saat terjadinya fotosintesis atau pada pagi hari. Bahan berupa daun sirsak diambil dari Kelurahan Taipa, Kecamatan Palu Utara, Propinsi Sulawesi Tengah.

\section{Pengolahan sampel}

Sampel daun Sirsak yang telah diambil akan dicuci bersih selanjutnya dilakukan perajangan kemudian bahan dipotong-potong kecil dan dikeringkan dengan cara dianginanginkan dan terlindung dari cahaya matahari langsung. Hal ini bertujuan agar zat aktif yang dikandungnya tidak terurai oleh pemanasan, selain itu pengeringan juga bertujuan agar simplisia awet, tidak rusak dan mengurangi kadar air, sehingga mencegah terjadinya pembusukan oleh jamur atau bakteri karna terhentinya proses enzimatik dalam jaringan tumbuhan yang selnya telah mati. Setelah bahan kemudian diblender hingga menjadi serbuk, dan dibuat infusa dengan konsentrasi $20 \%, 40 \%$ dan $60 \% \mathrm{~b} / \mathrm{v}$.

\section{Penyiapan hewan uji}

Hewan uji yang digunakan adalah mencit jantan, sehat, dewasa, berat 20 - $30 \mathrm{~g}$ dan diadaptasikan selama 1 minggu, mencit yang digunakan sebanyak 10 ekor yang dibagi menjadi 5 kelompok dan masing-masing kelompok terdiri dari 2 ekor. 


\section{Bahan}

Bahan-bahan yang digunakan pada penelitian ini meliputi Tablet paracetamol, ekstrak daun sirsak, mencit jantan, alkohol $70 \%$, Na CMC, aquadest, larutan pepton, kertas label.

\section{Peralatan}

Alat-alat yang digunakan pada penelitian ini meliputi Gelas kimia, gelas ukur 100 $\mathrm{ml}$, spoit oral $1 \mathrm{ml}$, labu ukur $100 \mathrm{ml}$, lumpang dan alu, meja percobaan, kandang, panci infus, stop watch, timbangan analitik, termometer, kertas saring, corong.

\section{Prosedur kerja}

a. Sebelum perlakuan, hewan uji diadaptasikan dalam ruang percobaan selama kurang lebih 18 jam, kemudian dipuasakan selama 6 jam sebelum perlakuan. Hewan uji kemudian dikelompokan menjadi 5 kelompok dan masing-masing terdiri dari 2 ekor mencit (Mus musculus).

b. Mengukur suhu rektal dari seluruh kelompok hewan percobaan untuk mengetahui suhu awal.

c. Menginduksi seluruh kelompok hewan percobaan dengan cara memberikan larutan pepton.

d. 1 jam setelah diinduksi, suhu rektal dari seluruh hewan percobaan diukur kembali untuk mengetahui peningkatan suhu setelah induksi.

e. Setelah diketahui peningkatan suhu pada hewan coba, maka masing-masing kelompok mendapat perlakuan yang berbeda, yaitu:

1. Kelompok 1 (satu) diberikan aquadest sebagai kontrol negatif.

2. Kelompok 2 (dua) diberikan infus daun sirsak dengan kosentrasi $20 \%$.

3. Kelompok 3 (tiga) diberikan infus daun sirsak dengan kosentrasi $40 \%$.

4. Kelompok 4 (empat) diberikan infus daun sirsak dengan kosentrasi $60 \%$.

5. Kelompok 5 (lima) diberikan larutan pembanding paracetamol sebagai kontrol positif.

f. 30 (tiga puluh) menit setelah perlakuan, suhu rektal diukur sampai dengan menit 120 dengan interval 30 menit untuk mengetahui penurunan suhu.

\section{Pembuatan bahan penelitian}

\section{Pembuatan infus daun sirsak}

Pembuatan infus daun sirsak dengan kosentrasi $20 \% \mathrm{~b} / \mathrm{v}$ dilakukan dengan menimbang simplisia daun sirsak sebanyak 20 gram, kemudian dimasukkan kedalam panci infus, ditambahkan air suling $50 \mathrm{ml}$ ( 2 kali berat simplisia) diaduk hingga semua permukaan simplisia menjadi basah, dibiarkan selama 10 menit lalu ditambahkan air 100 ml, kemudian dipanaskan selama 15 menit dihitung mulai suhu didalam panci mencapai $90^{\circ} \mathrm{c}$, sambil sesekali diaduk, selanjutnya diserkai dengan kain flanel dan dicukupkan volumenya $100 \mathrm{ml}$. Untuk infus $40 \%$ dan $60 \% \mathrm{~b} / \mathrm{v}$ dilakukan cara yang sama dengan menimbang bahan 40 gram dan 60 gram.

\section{Pembuatan larutan pepton 5\%}

Menimbang Pepton sebanyak 1 gram, kemudian dimasukan kedalam beker gelas dan dilarutkan dengan $20 \mathrm{ml}$ aquadest. Sambil diaduk. Dan untuk membuat mencit menjadi demam adalah $0,5 \mathrm{ml}$ secara subkutan. 


\section{Pembuatan larutan koloidal Na. CMC $1 \%$ b/v}

$\mathrm{Na}-\mathrm{CMC}$ ditimbng sebanyak 0,5 gr dimasukkan sedikit demi sedikit kedalam $50 \mathrm{ml}$ aquadest panas, sambil diaduk dengan batang pengaduk hingga membentuk larutan koloidal, dan volumenya dicukupkan dengan aquadest hingga $100 \mathrm{ml}$.

\section{Pembuatan suspensi parasetamol}

Ditimbang parasetamol 10 tablet, dihitung berat rata-ratanya, kemudian digerus di dalam lumpang dan ditimbang setara dengan hasil perhitungan dosis parasetamol. Ditambahkan larutan koloidal Na CMC 1\% sedikit demi sedikit sambil digerus hingga homogen lalu dimasukan dalam labu takar dicukupkan volumenya dengan larutan koloidal $\mathrm{Na}$ CMC 1\% hingga $100 \mathrm{ml}$.

\section{Pengumpulan dan analisis data}

Uji Efek Antipiretik Ekstrak Daun Sirsak (Annona muricata L.) Secara Oral Pada Mencit (Mus musculus), menggunakan uji annova. Teknik pengumpulan data dilakukan dengan pengamatan dan pengukuran suhu rektal mencit sebelum dan sesudah perlakuan dan dengan menggunakan aquadest sebagai kontrol negatif dan parasetamol sebagai kontrol positif.

\section{HASIL DAN PEMBAHASAN}

\section{Hasil penelitian}

Hasil penelitian mengenai ekstrak daun sirsak (Annona muricata L.) secara oral pada mencit (Mus musculus) sebagai berikut :

Tabel 4.1 Hasil pengukuran suhu rektal sebelum dan sesudah perlakuan

\begin{tabular}{|c|c|c|c|c|c|c|}
\hline \multirow{3}{*}{ Perlakuan } & \multirow{2}{*}{ Replikasi } & \multirow{2}{*}{ U1 } & \multirow{2}{*}{ U2 } & \multicolumn{3}{|c|}{ Suhu setelah menit ke - } \\
\cline { 4 - 7 } & & & & $\mathbf{3 0}$ & $\mathbf{6 0}$ & $\mathbf{1 2 0}$ \\
\hline \multirow{4}{*}{$\mathbf{A}$} & I & 33,7 & 35,8 & 33,2 & 32,6 & 32,4 \\
\cline { 2 - 7 } & II & 33,3 & 34,7 & 33,7 & 32,7 & 32,1 \\
\cline { 2 - 7 } & Jumlah & 67 & 70,5 & 66,9 & 65,3 & 64,5 \\
\cline { 2 - 7 } & Rata-rata & 22,33 & 23,5 & 22,3 & 21,76 & 21,5 \\
\hline \multirow{4}{*}{ B } & I & 34,7 & 36 & 33,9 & 32,2 & 32,0 \\
\cline { 2 - 7 } & II & 32,4 & 35,6 & 34,1 & 33,2 & 32,0 \\
\cline { 2 - 7 } & Jumlah & 67,1 & 71,6 & 68 & 64,4 & 64 \\
\cline { 2 - 7 } & Rata-rata & 22,36 & 23,86 & 22,66 & 21,46 & 21,33 \\
\hline \multirow{4}{*}{ C } & I & 33,8 & 35,3 & 34,2 & 33,2 & 32,1 \\
\cline { 2 - 7 } & II & 33,5 & 36,1 & 33,2 & 32,3 & 32,0 \\
\cline { 2 - 7 } & Jumlah & 67,3 & 71,4 & 67,4 & 65,5 & 64,1 \\
\cline { 2 - 7 } & Rata-rata & 22,43 & 23,8 & 22,46 & 21,83 & 21,36 \\
\hline \multirow{4}{*}{ D } & I & 32,8 & 35 & 33,2 & 32,3 & 32,2 \\
\cline { 2 - 7 } & II & 32,9 & 35,7 & 33,2 & 32,7 & 32,5 \\
\hline
\end{tabular}




\begin{tabular}{|c|c|c|c|c|c|c|}
\hline \multirow{4}{*}{} & Jumlah & 65,7 & 70,7 & 66,4 & 65 & 64,7 \\
\cline { 2 - 7 } & Rata-rata & 21,9 & 23,56 & 22,13 & 21,66 & 21,56 \\
\hline \multirow{4}{*}{ E } & I & 32,6 & 35,3 & 32,3 & 32,0 & 32,0 \\
\cline { 2 - 7 } & II & 33,2 & 34,5 & 32,4 & 32,1 & 32,0 \\
\cline { 2 - 7 } & Jumlah & 65,8 & 69,8 & 64,7 & 64,1 & 64 \\
\cline { 2 - 7 } & Rata-rata & 21,93 & 23,26 & 21,56 & 21,36 & 21,33 \\
\hline
\end{tabular}

$\begin{array}{cl}\text { Keterangan } & \text { : } \\ \text { Pk } & \text { : Perlakuan } \\ \mathrm{U} 1 & \text { : Suhu awal } \\ \mathrm{U} 2 & \text { : Suhu setelah induksi } \\ \mathrm{A} & \text { : Kelompok } 1 \text { yang diberikan Aquadest } \\ \mathrm{B} & \begin{array}{l}\text { : Kelompok } 2 \text { yang diberikan ekstrak daun sirsak (Annona } \\ \text { muricata L.) dengan konsentrasi 20\% }\end{array} \\ \mathrm{C} & \begin{array}{l}\text { : Kelompok } 3 \text { yang diberikan ekstrak daun sirsak (Annona } \\ \text { muricata L.) dengan konsentrasi 40\% }\end{array} \\ \mathrm{D} & \begin{array}{l}\text { : Kelompok } 4 \text { yang diberikan ekstrak daun sirsak (Annona } \\ \text { muricata L.) dengan konsentrasi } 60 \%\end{array} \\ \mathrm{E} \text { : Kelompok 5 yang diberikan suspensi parasetamol. }\end{array}$

\section{Pembahasan}

Antipiretik merupakan senyawa yang digunakan untuk menurunkan demam dengan berbagai penyebab (inflamasi dan neoplasma). Selain itu demam juga biasanya terjadi akibat tubuh terpapar infeksi mikroorganisme (Virus, bakteri, parasit). Demam juga bisa disebabkan oleh faktor non infeksi seperti komleks imun. Demam adalah gejala umum jika terserang sakit. Demam juga merupakan suatu keadaan dimana terjadi peningkatan suhu, dimana suhu tersebut melebihi dari suhu tubuh normal.

Sirsak (Annona muricata L.) merupakan tanaman tropis yang buahnya memiliki aroma dan rasa khas. Sirsak lebih dikenal sebagai tanaman buah, namun seiring dengan penelitian tanaman ini populer sebagai tanaman obat terutama daunnya memiliki banyak khasiat terhadap beberapa penyakit, diantaranya demam, tekanan darah tinggi, tumor, dan meredakan nyeri. Adapun kandungan kimia yang dikandung oleh tanaman sirsak yang berkhasiat sebagai antipiretik adalah flavonoid. Flavonoid menghambat enzim utama dalam biosintesis prostaglandin, siklooksigenase.

Sebelum perlakuan dilakukan, daun sirsak terlebih dahulu diekstraksi. Tujuan dilakukan ekstraksi adalah untuk memisahkan bahan aktif dan dipekatkan untuk memperoleh rasa lebih enak dibandingkan bahan bakunya. Adapun metode ekstraksi yang digunakan adalah metode ekstraksi secara panas, yaitu metode infudasi. Infus adalah sediaan cair yang dibuat dengan menyari simplisia dengan air pada $90^{\circ} \mathrm{C}$ selama 15 menit, dihitung setelah suhu mencapai $90^{\circ} \mathrm{C}$. Infudasi adalah proses penyarian yang umumnya digunakan untuk menyari zat kandungan aktif yang larut dalam air dan bahan-bahan nabati. Oleh sebab itu sari yang diperoleh dengan cara ini tidak boleh disimpan lebih dari 24 jam. Digunakan metode infudasi karena bahan yang diekstraksi adalah bagian tanaman yang lunak yaitu daun. Selain itu dalam penelitian yang digunakan sebagai faktor penyebab demamnya adalah pepton, yang memberikan efek demam kepada mencit (Mus musculus). 
Ekstak daun sirsak (Annona muricata L.) dibuat dengan beberapa kosentrasi yaitu $20 \%, 40 \%$ dan $60 \%$. Selain itu pada penelitian ini juga digunakan kontrol negatif yaitu aquadest, dan kontrol positifnya adalah paracetamol. Hal ini dimaksudkan untuk mengetahui pada kosentrasi berapa ekstrak daun sirsak (Annona muricata L.) efektif memberikan efek antipiretik yang paling baik pada mencit (Mus musculus), dengan mengukur suhu rektal pada mencit (Mus musculus).

Mencit (Mus musculus) yang digunakan pada penelitian ini memiliki bobot badan rata-rata $20 \mathrm{~g}$, dan sebelum perlakuan mencit (Mus musculus) tersebut dipuasakan terlebih dahulu selama 8 jam. Hal ini bertujuan untuk mengurangi variasi biologis yang nantinya akan terjadi, yang akan mempengaruhi hasil penelitian. Karena dengan perubahan biologis tersebut akan mempengaruhi sistem pencernaan pada mencit (Mus musculus).

Dari hasil penelitian yang dilakukan dengan metode analisa spss, dapat dilihat bahwa pada kontrol negatif mendapatkan hasil signifikan $(7,000)$ dan kontrol positif (11,000*) sehingga kelompok negatif tidak memiliki efek yang signifikan sebagai entipiretik, pada konsentrasi $20 \%$ memiliki nilai $(8,500)$, konsentrasi $40 \%(8,000)$, dan pada kosentrasi $60 \%$ mendapatkan hasil signifikan $\left(11,000^{*}\right)$ yang artinya paling efektif dan memiliki nilai yang sama dengan kelompok kontrol positif yang memberikan efek antipiretik dibandingkan dengan konsentrasi lainnya. Dan nilai signifikan yaitu $<0,05$ berarti H0 ditolak, dan terjadi perbedaan secara nyata antara semua perlakuan.

\section{KESIMPULAN}

Berdasarkan hasil penelitian dan pengolahan data yang telah dilakukan terhadap sampel ekstrak Daun Sirsak (Annona muricata L.) maka dapat disimpulkan bahwa Ekstrak daun sirsak (Annona muricata L.) memiliki efek Antipiretik terhadap mencit (Mus musculus). Efek antipiretik ekstrak daun sirsak (Annona muricata L.) mempunyai perbedaan efektifitas yaitu pada konsentrasi 60\% dibandingkan konsentrasi $20 \%$ dan $40 \%$.

\section{DAFTAR PUSTAKA}

1. Syamsu,H, 2005. Ramuan Tradisional ala 12 Etnis Indonesia. Penebar Swadaya. Jakarta.

2. Wahjoedi, B., B. Dzulkarnain, S. Bakar, Nurendah P. \& Subanu, 2006. Efek Antipiretik Beberapa Tanaman Obat, Buletin Penelitian Kesehatan Vol IX, No.2, hal: 11.

3. Lestari Handayani, 2005. Pemanfaatan Obat Tradisional dalam Menangani Masalah Kesehatan, Majalah Kedokteran Indonesia.

4. Drs. H, Hendro Sunarjo, 2007. Mengenal Sirsak \& Srikaya. Penebar Swadaya. Jakarta.

5. Anonim. 1989. Sediaan Galenik. Jakarta : Dirjen POM. 10.28

6. Anonim. 1979. Farmakope Indonesia Ed.3. Jakarta : Dirjen POM.

7. Amori, G. (1996). Mus musculus. 2007 IUCN Redd List of Threatened Species. IUCN 2007. Diakses tanggal 26 Juni 2011

8. Suharjono D.1995. Percobaan Hewan Laboratorium. Yogyakarta. Gajah Mada University Press, hal. 207.

9. Kusumawati Diah. 2006. Bersahabat dengan hewan coba. Gajah Mada University Press. Yogyakarta.

10. Tim Penyusun. 1987. Pemeliharaan, Pengembangbiakan dan Penggunaan Hewan Percobaan Didaerah Tropis. Universitas Indonesia. Jakarta. 